\title{
PEMBELAJARAN MATEMATIKA SECARA DARING BAGI MAHASISWA SELAMA PANDEMI COVID-19 (STUDI FENOMENOLOGI)
}

\author{
Author: \\ Bagus Aulia Iskandar ${ }^{1}$ \\ Zulparis $^{2}$ \\ Mubarok $^{3}$ \\ Afiliation: \\ STKIP Islam Sabilal Muhtadin \\ Banjarmasin ${ }^{1,2,3}$ \\ Corresponding email \\ Bagusauliaiskandar@gmail.com ${ }^{1}$ \\ Zulparis1@gmail.com ${ }^{2}$ \\ hzmubarok@gmail.com ${ }^{3}$
}

Histori Naskah: Submit: 2021-08-30 Accepted: 2021-09-10 Published: 2021-12-01

This is an Creative Commons License This work is licensed under a Creative Commons Attribution-NonCommercial 4.0

International License

\begin{abstract}
Abstrak:
Latar belakang: Di masa pandemi Covid-19 dilakukan Pembatasan Sosial Berskala Besar (PSBB) hal ini berdampak kepada pelaksanaan perkuliahan yang dilakukan secara tatap muka (daring). Mahasiswa sebagian masih belum terbiasa dengan metode ini sehingga dalam pelaksanaannya ada kendala yang mengakibatkan pelaksanaan perkuliahan tidak bisa secara optimal. Penelitian ini bertujuan untuk mengetahui kendala yang dialami mahasiswa selama pelaksanaan kuliah daring untuk mata kuliah praktik pembelajaran Matematika pada semester ganjil 2020/2021, Metode penelitian: Dalam penelitian ini desain penelitian yang menggunakan metode kualitatif dengan pendekatan fenomenologi untuk mendapatkan informasi dari partisipan mengenai pelaksanaan perkuliah daring untuk mata kuliah praktik pembelajaran Matematika selama pandemi Covid-19. Jumlah partisipan ada dua orang yang merupakan mahasiswa yang aktif dalam pelaksanaan perkuliahan daring. Analisis data fenomenologi meliputi kategorisasi, reduksi, dan penarikan tema sejenis.

Hasil penelitian: Berdasarkan penelitian diperoleh hasil sebagai berikut: pertama, faktor kendala pelaksanaan perkuliahan daring adalah koneksi jaringan. Kedua faktor lain yang mempengaruhi adalah jadwal kuliah yang tentative, dan keterlambatan dalam menerima informasi perkuliahan.

Kesimpulan: Tidak optimalnya perkuliahan daring selama masa pandemi dikarenakan beberapa faktor yang mempengaruhi kelancaran pelaksanaan pembelajaran.
\end{abstract}

Kata kunci: kendala, mahasiswa, matematika, perkuliahan daring.

\section{Pendahuluan}

Dampak dari virus Covid-19 dimulai sejak bulan Februari 2020, yang telah mengakibatkan perubahan pada tatanan kehidupan masyarakat, Semenjak diberlakukannya work from home melalui surat yang dikeluarkan oleh Kementrian PAN RB nomor 19 tahun 2020 tentang penyesuaian sistem kerja Aparatur Sipil Negara dalam upaya pencegahan penyebaran Covid-19 di lingkungan pemerintah adalah sebagai pedoman bagi instansi pemerintah maupun lembaga dan daerah dalam melaksanakan tugas kedinasan dengan bekerja dari rumah atau tempat tinggalnya dalam meminimalisir penyebaran Covid-19.

STKIP ISM Banjarmasin sebagai salah satu perguruan tinggi di kota Banjarmasin juga terkena dampaknya, untuk mencegah terjadinya penularan virus Covid-19 maka diberlakukanlah belajar dari rumah secara daring. Wahyu Dwi Mulyono (2020) Pembelajaran daring menjadi masalah bagi mahasiswa, karena 
kebanyakan mereka melakukan online di daerah masing-masing yang memiliki perbedaan kondisi jaringan internetnya. Untuk itu Ketua STKIP ISM Banjarmasin telah memberikan surat edaran untuk melaksanakan perkuliahan dari rumah semenjak tanggal 17 Maret 2020, dengan surat keputusan Nomor: 013//STKIPISM/BJM/III/2020.

Selama pelaksanaan perkuliahan dari rumah, proses pemberian materi, penugasan, dan ujian dilakukan secara daring dengan menggunakan aplikasi Whatsapp, Zoom Meeting, Google Meet, dan lain-lain. Dengan metode belajar baru yang di terapkan, dosen dan mahasiswa merasakan hal yang berbeda dibandingkan dengan belajar bertatap muka langsung. Dimana metode belajar daring menjadi sebuah kebiasaan baru yang harus dilaksanakan selama pandemi Covid-19 ini. Anggraini, Mauliska, Sholehah (2020) tidak hanya dalam penyampaian materi pembelajaran, tetapi juga perubahan dalam kemampuan berbagai kompetensi mahasiswa. Melalui e-learning, mahasiswa tidak hanya mendengarkan uraian materi dari dosen atau pengajar saja tetapi juga aktif mengamati, melakukan, mendemonstrasikan, dan sebagainya.

Disini peneliti sekaligus dosen pengampu mata kuliah praktik pembelajaran Matematika merasakan kecendrungan adanya kendala yang dirasakan mahasiswa selama melaksanakan perkuliahan daring yang berbeda pelaksanaannya jika dilakukan secara luring. Hal ini dapat dilihat dari beberapa faktor sebagai berikut: 1) Intensitas kehadiran mahasiswa selama pelaksanaan kontrak perkuliahan; 2) keaktifan mahasiswa dalam perkuliahan (Dialog, tanya jawab, dan diskusi kelompok); 3) Pengumpulan tugas yang sering terlambat; 4) Penurunan nilai mahasiswa dibandingkan semester yang sebelumnya.

Dari latar belakang ini peneliti tertarik untuk membahas study fenomenologi tentang kendala perkuliahan praktik Matematika bagi mahasiswa selama pandemi Covid-19, yang bertujuan untuk menggali informasi kendala praktik pembelajaran Matematika secara daring yang dilaksanakan selama pandemi Covid-19 selama semester ganjil tahun akademik 2020/2021.

Penelitian ini diharapkan mampu memberikan informasi tentang kendala perkuliahan praktik pembelajaran Matematika secara daring bagi dosen dan mahasiswa dari pendekatan studi fenomenologi.

\section{Studi Literatur}

\section{Kendala dalam Pembelajaran}

Kondisi di pelaksanaan perkuliahan daring untuk mata pelajaran praktik pembelajaran matematika dirasa masih belum optial. Rosihudin dalam Millati (2020:13) kendala dalam pembelajaran adalah permasalahan yang mengganggu, menghambat, atau mempersulit bahkan mengakibatkan kegagalan dalam mencapai tujuan pembelajaran. Faktor yang menyebabkan terjadinya kendala pembelajaran adalah pendekatan yang digunakan, kurikulum, dan profesionalisme pendidik. Hermansyah, Annur (2020) Meski tidak dapat bertatap muka, dosen harus berpikir keras agar pembelajaran yang disampaikan tetap dapat menarik minat mahasiswa mengikutinya. Sebagai sebuah proses pembelajaran dihadapkan pada beragam kendala, masalah interaksi belajar mengajar merupakan masalah yang kompleks karena melibatkan berbagai faktor yang saling terkait satu sama lain. Khasanah, Syarifah (2021) Aplikasi Zoom merupakan salah satu e-learning yang dapat mendukung aktivitas pembelajaran secara daring

Menurut Sanjaya dalam Millati (2020: 15) pembelajaran daring adalah pembelajaran yang memanfaatkan teknologi atau jaringan internet dalam proses pembelajaran. Perkembangan teknologi secara cepat telah membawa peradaban ini menuju ke revolusi industri 4.0. Sri Widayati (2020) Era globalisasi dan revolusi industri 4.0 seperti saat ini menuntut seluruh perguruan tinggi untuk menyediakan layanan menggunakan teknologi digital dalam pembelajaran. Penyediaan layanan pendidikan menggunakan teknologi digital bertujuan untuk memudahkan mahasiswa mengakses materi-materi terkait perkuliahan, sehingga 


\section{Edu Cendikia: Jurnal Ilmiah Kependidikan}

Volume: 1 | Nomor 3 | Desember 2021 | E-ISSN: 2798-365X | DOI: 10.47709/educendikia.v1i3.1076

mahasiswa dapat belajar kapan saja dan di mana saja. Saat ini kita berada di zaman dimana teknologi dan internet mendukung berbagai segi kehidupan. Wabah covid-19 mendadak menyerang kita dan semua siswa yang masih belum terbiasa dengan pemanfaatan teknologi dipaksa untuk menggunakannya. Perubahan drastis ini tentunya tidak mudah diterima bagi sebagian pihak namun untuk saat ini hanya teknologi dengan pembelajaran dari rumah yang mampu menjadi jembatan untuk tetap berlangsungnya transfer ilmu. Nurhabibah, Hanikah, Widiawati (2020). Metode pembelajaran dengan memanfaatkan teknologi melalui dalam jaringan (daring), memiliki tantangan tersendiri di saat mewabahnya pandemi saat ini. Terdapat beberapa keunggulan dan kelemahan dalam pembelajaran daring.

Wabah covid-19 yang menyebar di Indonesia tidak menyebabkan penyelenggara pendidikan mulai dari sekolah dan perguruan tinggi turut melakukan perubahan strategi dalam melaksanakan pembelajaran. Ruang pembelajaran mulai dikosongkan secara massal. Nastit, Hayati (2020). Pembelajaran daring memang telah menjadi solusi pembelajaran alternatif bagi dosen dan mahasiswa di tengah pandemi ini. Belajar dari rumah menjadi sebuah kepastian untuk memutus rantai covid-19. Dalam situasi seperti ini semua unsur perlu beradaptasi dengan cepat. Teknologi Informasi (IT) dan komunikasi tidak lagi gagap dengan pemanfaatan teknologi dalam proses belajar mengajar. Pembelajaran melalui audio-visual digital atau menggunakan internet sudah biasa dilakukan sehari-hari, di rumah. Dalam pelaksanaan daring ini seorang guru hendaknya mengetahui langkah-langkah pembelajaran daring yaitu:

a. Pendidik harus memanfaatkan waktu dan memberi tugas via Google Classroom, pre-test atau pemberian tugas dengan pemanfaatan Google Drive. Hal ini mutlak harus dilakukan untuk mentransfer pengetahuan kepada peserta didik.

b. Pendidik harus menyajikan pembelajaran yang terencana dan efektif dalam keterbatasan waktu.

c. Dalam kegiatan akhir pembelajaran daring ini hendaknya seorang pendidik memberikan penguatan karakter/motivasi kepada peserta didik agar siap dalam kondisi apapun seperti yang terjadi saat pandemi Corona ini.

\section{Metode Penelitian}

Penelitian menggunakan pendekatan fenomologi yaitu penelitian yang biasa diartikan sebagai pengalaman subjektif atau pengalaman fenomenologikal, Fenomenologi merupakan pandangan berfikir yang menekankan pada fokus pengalaman-pengalaman subjektif manusia dan interpretasi dunia. Dengan menggunakan pendekatan fenomenologi memungkinkan untuk dapat mengungkapkan problematika dosen dan mahasiswa dalam melaksanakan perkuliahan daring.

Partisipan yang terlibat dalam penelitian ini ada 2 orang mahasiswa dengan kriteria: 1) Merupakan mahasiswa STKIP ISM Banjarmasin; 2) Mengambil mata kuliah Praktik Pembelajaran Matematika; 3) Aktif dalam perkuliahan daring; 4) Bersedia sebagai partisipan penelitian. Peneliti disini juga sebagai dosen pengampu mata kuliah praktik pembelajaran matematika peran peneliti sebagai alat pengumpul data utama. dan mengumpulkan data yang dibutuhkan.

Penelitian dilakukan di lingkungan STKIP Islam Sabilal Muhtadin lewat wawancara sebagai media pengumpulan datanya Teknik pengumpulan data pada penelitian ini adalah menggunakan teknik wawancara menggunakan panduan yang dibuat oleh peneliti agar kegiatan tersebut menjadi sistematis dan lebih mudah. Dilaksanakan pada semester ganjil tahun akademik 2020/2021 dari bulan Desember-Januari.

Dalam Penelitian ini analisis yang dilakukan dalam beberapa tahapan yaitu: Pertama data yang diperoleh dari hasil wawancara di indekskan dalam tabel; Kedua membuat inisial bagi partisipan guna pengkodingan; Ketiga mempelajari data dan mempelajari kata kunci; Keempat menarik dan mereduksi data yang sesuai dengan kendala pelaksanaan perkuliahan daring; Kelima membuat kesimpulan dan penulisan laporan. 
Sedangkan prosedur pelaksanaan penelitian dimulai dari menetapkan tujuan penelitian, menentukan setting dan subjek penelitian, membuat desain dan instrumen penelitian, mengumpulkan data, mengolah data, menganalis data, dan menyajikan data.

\section{Hasil}

Pemaknaan perkuliahan daring merupakan perkuliahan yang memanfaatkan akses internet dengan menggunakan audio video secara terpisah (HR.AKD:1). Segala bentuk materi, tes, dan komunikasi didistribusikan serta dilakukan melalui online melalui aplikasi maupun jejaring sosial. Handayani (2020) Selain Whatsapp Group (WA Group),media lain yang digunakan dalam pembelajaran daring adalah platform Zoom Meeting. Zoom Meeting sendiri merupakan sebuah media pembelajaran menggunakan video. Ada juga aplikasi yang digunakan seperti Google Classroom, Google Meet, Edmudo dan Zoom.(NH.AKD:1) Fitriyani, Fauzi, dkk (2020) Pembelajaran daring merupakan sebuah inovasi pendidikan yang melibatkan unsur teknologi informasi dalam pembelajaran.

Penggunaan aplikasi selama daring tergantung dari pihak dosen yang meminta, aplikasi tersebut sangat membantu namun sangat sulit apabila terjadi masalah di jaringan. (NH.A:2). Aplikasi yang sering digunakan adalah :

a) Zoom meeting

Zoom merupakan aplikasi komunikasi yang menggunakan video seperti sedang video call secara bersamaan dan dapat memuat banyak orang. Aplikasi tersebut dapat digunakan dalam berbagai perangkat seluler seperti heand phone, desktop, hingga telepon dan system ruang sehingga dapat memudahkan dalam proses pembelajaran praktik matematika. Fadila, Nadiroh, dkk, (2021) Dalam pembelajaran secara synchronous seperti menggunakan aplikasi zoom atau yang serupa terkadang terdapat kendala koneksi internet yang menyebabkan penyampaian materi kurang jelas dan pemahaman materi kurang mendalam

b) Whats App

Whats App adalah aplikasi untuk smartphone dengan basic mirip blackberry messenger. WhatsApp merupakan aplikasi pesan yang memungkinkan kita bertukar pesan serta dapat membuat grub pesan sehingga mempermudah untuk pemberitahuan dalam proses belajar mengajar.(HR.A:2)

Dalam pelaksanaan perkuliahan daring lebih baik menggunakan wifi (NH.J:3), akan tetapi mahasiswa yang tidak memilikinya terpaksa menggunakan jaringan seluler. Hal ini sangat menguras, karena ternyata ada beberapa mahasiswa yang tidak mendapat bantuan kuota dari pemerintah. Dan koneksi internetnya tidak stabil sehingga sering terputus saat pembelajaran berlangsung.(HR.J:3).

Perkuliahan daring di STKIP ISM Banjarmasin sudah bagus, teratur dan penuh persipaan. Kendalanya ada di jaringan. Hanya saja bagaimana agar tidak membosankan agar mahasiswa tidak bosan dalam belajar. (NH.P:4). Selanjutnya agar jadwal agar jangan tentative sehingga mahasiswa dapat maksimal dalam mengikuti proses pembelajaran (HR.P:4)

Perbandingan kehadiran seimbang, tergantung dari koordinasi dosennya. Keterlambatan mahasiswa dikarenakan koneksi internet, jam kuliah yang tentative, dan keterlambatan mahasiswa mengetahui informasi tentang perkuliahan. (HR.K:5). Namun akan lebih banyak jika dilakukan secara luring, karena kebanyakan mahasiswa dapat membuat alasan jika tidak berhadir dalam perkuliahan (NH.P:5)

Dalam pelaksanaan perkuliahan daring yang ideal diperlukan strategi agar pembelajaran tidak membosankan, kedisiplinan dengan hadir sesuai jadwal. Jika ada perubahan jadwal atau tidak dapat berhadir dapat diberitahukan sebelumnya (NH.MKI:6). Lebih lanjut metode yang ideal itu seperti : 
a) Membangkitkan motivasi saat mengajar dan gunakan media apapun agar siswa termotivasi dan lebih bersemangat dalam mengikuti perkuliahan.

b) Interaktif saat melakukan perkuliahan.

c) Membuat siswa memahami apa yang dipelajari baru menyuruh siswa mempelajari materi yang diberikan.

d) Memberikan pemahaman serta kemudahan dalam memberikan tugas kepada mahasiswa dan berikan petunjuk agar siswa mudah dalam mengerjakan tugas.

e) Membangun semangat berkolaborasi saat perkuliahan berlangsung sehingga terjalin kerjasama antar mahasiswa dan dosen.(HR.MKI:6)

\section{Pembahasan}

Perkuliahan daring menjadi pilihan yang dilaksanakan selama pandemi Covid-19 ini. Hal ini dikarenakan dosen dan mahasiswa tidak bisa bertatap muka, sehingga harus dibantu dengan koneksi internet dan aplikasi. Dalam pelaksanaannya terdapat kendala yang mengakibatkan baik mahasiswa dan dosen tidak dapat melaksanakan perkuliahan secara optimal. Hasanah, lestari,dkk (2020) Pelaksanaan aktivitas belajar dirumah dengan media daring menuntut mahasiswa menguasai media yang beragam. Dengan keberanekaragaman media daring yang sebelumnya belum pernah menggunaannya, mahasiswa dituntut untuk menguasainya. Aktivitas perkuliahan online yang beragam mengakibatkan penggunaan media atau aplikassi daring yang beragam pula untuk keefektifan jalannya perkuliahan

Ketika pemaknaan pemikiran digali dari dua partisipan terdapat beberapa pemaknaan tantang kendala yang dialami selama perkuliahan daring selama perkuliahan daring untuk mata kuliah praktik pembelajaran Matematika.

a) Untuk partisipan pertama mengatakan koneksi internet yang stabil seperti wifi sangat mendukung dalam melaksanakan perkuliahan daring, penyebab ketidak hadiran mahasiswa sebagian besar dikarenakan koneksi, jadwal yang tentative, dan keterlambatan dalam menerima informasi. Dalam pelaksanaannya supaya tidak membosankan sebaiknya strategi pembelajaran yang digunakan dapat memotivasi, interaktif, dapat membuat siswa paham, kolaborasi, dan dapat diberikan kemudahan dalam pengerjaan tugas. Nasrah, Muafiah (2020) Pembelajaran daring dapat efektif apabila dibarengi dengan kemandirian mahasiswa dalam mengatur jadwal belajarnya

b) Partisipan kedua mengatakan jika penggunaan wifi lebih baik dibandingkan jaringan seluler, untuk pelaksanaan perkuliahan sudah bagus, namun harus dibarengi metode yang tidak membosankan dan bisa memberikan konfirmasi jika ada ketidak hadiran

\section{Kesimpulan}

Kendala dalam pelaksanaan perkuliahan daring selama pandemi Covid-19 ini lebih banyak kepada permasalahan jaringan yang kurang mendukung. Hal ini dikarenakan mahasiswa yang masih bergantung pada jarinagn seluluer dalam melaksanakan perkuliahan daring, sehingga pada saat pelaksanaannya banyak yang terputus-putus. Selain itu ada juga mahasiswa yang tidak mendapatkan bantuan kuota, jadi menghabiskan biaya dalam melaksanakan perkuliahan daring. Widiyono (2020) Keluhan secara umum terjadi pada jaringan internet yang tidak stabil, bahan materi yang belum bisa disampaikan secara penuh setiap pertemuan, minimnya sarana media pendukung dalam aktivitas belajar secara daring. Faktor lain juga seperti mahasiswa yang membuat alasan dengan mengaitkannya kepada faktor koneksi, keterlambatan dalam menerima informasi, dan jadwal yang tentative membuat pelaksanaan perkuliahan daring tidak maksimal. lebih lanjut pelaksanaan perkuliahan ideal yang diharapkan mahasiswa adalah, mampu memotivasi, interaktif, kolaborasi, mampu memahamkan kepada siswa, dan memberikan kemudahan dalam tugas. 


\section{Referensi}

Widiyono, Aan. 2020. efektifitas Perkuliahan Daring (Online) Pada Mahasiswa PGSD di Saat pandemi Covid 19. Jurnal Pendidikan UNISNU. Vol. 2 :169-177; UNISNU Jepara.

Widodo, Arif. 2020. Problematika Pembelajaran daring Dalam Perpektif Mahasiswa. Jurnal Pendidikan dan pembelajaran di Sekolah Dasar PGSD. Vol 4, No. 2; Universitas Muhammadiyah Surabaya.

Rigianti, Henry Aditia. 2020. Kendala Pembelajaran Daring Guru Sekolah Dasar Di Kabupaten Banjarnegara. Jurnal Pendidikan Sekolah Dasar. Vol. 7, No. 2; Universitas PGRI Yogyakarta Indonesia.

Dewi, Wahyu Aji Fatma. 2020 Dampak Covid-19 Terhadap Implementasi Pembelajaran Daring Di Sekolah Dasar. Vol. 2, No 1; Universitas Kristen Satya Wacana.

Mulyono, W. D. (2020). Respon Mahasiswa Terhadap Pembelajaran Daring Pada Masa Pandemi Covid19. Steam Engineering, 2(1), 23-30.

Anggraini, V. A., Mauliska, N., \& Sholehah, M. A. (2020). Pembelajaran Daring Mahasiswa Tadris Matematika dengan Menerapkan E-Learning di Tengah Pandemi Covid-19. KULIDAWA, 1(2), 61-64.

Nurhabibah, P., Hanikah, H., \& Widiawati, H. Aplikasi Pilihan Pendukung Pembelajaran Daring pada Mahasiswa Pendidikan Guru Sekolah Dasar. DWIJA CENDEKIA: Jurnal Riset Pedagogik, 4(2), 257-264.

Khasanah, S. U., \& Syarifah, A. (2021). Persepsi Mahasiswa Pendidikan Bahasa Inggris UIN Sunan Ampel Surabaya Terhadap Pembelajaran Daring Via Zoom Pada Masa Pandemi Covid-19. Edunesia: Jurnal Ilmiah Pendidikan, 2(1), 23-33.

Handayani, C. D. I. (2020). Efektifitas Pembelajaran Melalui Media Daring Ditinjau Dari Hasil Belajar Mahasiswa Pada Masa Pandemi Covid 19. Kajian Ekonomi dan Bisnis, 15(2).

Annur, M. F., \& Hermansyah, H. (2020). Analisis kesulitan mahasiswa pendidikan matematika dalam pembelajaran daring pada masa pandemi covid-19. Paedagoria: Jurnal Kajian, Penelitian dan Pengembangan Kependidikan, 11(2), 195-201.

Widayati, S., Hotimah, N., \& Rakhmawati, N. I. S. (2020). Respon Mahasiswa Pada Proses Pembelajaran Mata Kuliah Daring. Child Education Journal, 2(1), 48-52.

Nastiti, R., \& Hayati, N. (2020). Pembelajaran Daring pada Pendidikan Tinggi: Tantangan Bagi Mahasiswa dan Dosen di Tengah Pandemi. INOBIS: Jurnal Inovasi Bisnis dan Manajemen Indonesia, 3(3), 378-390.

Fadila, R. N., Nadiroh, T. A., Juliana, R., Zulfa, P. Z. H., \& Ibrahim, I. (2021). Kemandirian belajar secara daring sebagai prediktor hasil belajar mahasiswa Pendidikan Matematika UIN Sunan Kalijaga. Jurnal Cendekia: Jurnal Pendidikan Matematika, 5(2), 880-891.

Fitriyani, Y., Fauzi, I., \& Sari, M. Z. (2020). Motivasi belajar mahasiswa pada pembelajaran daring selama pandemik covid-19. Jurnal Kependidikan: Jurnal Hasil Penelitian dan Kajian Kepustakaan di Bidang Pendidikan, Pengajaran dan Pembelajaran, 6(2), 165-175. 
Edu Cendikia: Jurnal Ilmiah Kependidikan

Volume: 1 | Nomor 3 | Desember 2021 | E-ISSN: 2798-365X | DOI: 10.47709/educendikia.v1i3.1076

Hasanah, A., Lestari, A. S., Rahman, A. Y., \& Daniel, Y. I. (2020). Analisis aktivitas belajar daring mahasiswa pada pandemi Covid-19.

Nasrah, N., \& Muafiah, A. M. A. (2020). Analisis Motivasi Belajar Dan Hasil Belajar Daring Mahasiswa Pada Masa Pandemik Covid-19. JRPD (Jurnal Riset Pendidikan Dasar), 3(2), 207-213.

Widiyono, A. (2020). Efektifitas perkuliahan daring (online) pada mahasiswa pgsd di saat pandemi covid 19. Jurnal Pendidikan, 8(2), 169-177. 